\title{
Legal Protection of Women and Children in The Perspective of Human Rights
}

\author{
Ni Putu Rai Yuliartini \\ \{raiyuliartini@undiksha.ac.id\} \\ Universitas Pendidikan Ganesha, Indonesia
}

\begin{abstract}
The increase in legal material products, apparatus development, legal facilities and infrastructure has not been followed by real steps and the seriousness of the government and law enforcement officers in implementing and enforcing the law. The occurrence of interference in the judicial process, as well as overlapping and legal confusion resulted in a legal crisis in Indonesia. Such legal conditions result in the protection and respect of human rights in Indonesia is still apprehensive which can be seen from various human rights violations, including in the form of acts of violence, discrimination and arbitrariness. Realizing the importance of women and children obtaining adequate legal protection, especially from various forms of human trafficking (trafficking in person) amidst the diminishing attitude of tolerance and respect among fellow citizens. Realizing the importance of women and children obtaining adequate legal protection, especially from various forms of violence and violations of their rights in the midst of the diminishing attitude of tolerance and respect among fellow citizens. Women and children are creations of God Almighty, their dignity and self-respect need to be protected, and their right to live is guaranteed to grow and develop according to their nature and nature. Therefore, all forms of treatment that interfere with and destroy their basic rights in various forms of inhumane use and exploitation must be stopped immediately without exception.
\end{abstract}

Keywords: legal protection, women, children, human rights.

\section{Introduction}

Indonesia is a state of law that upholds justice and diversity including human rights. As intended in Article 27 paragraph (1) of the 1945 Constitution, that the recognition of the principle of equality is applied to all citizens without exception. This principle of equality certainly aims to eliminate and eliminate discrimination. Based on this principle, every citizen is considered to have equal rights before the law and government. Every citizen should be viewed as equal to each other without comparing religion, race, ethnicity, culture, gender, creed, position, position, or class. This is also supported by a statement from Moempoeni Martojo who said that: "The term citizen of course means both women and men". Based on the statements submitted by every citizen must be treated equally and get the appropriate rights, whether male or female. It means that the position of men and women will not be debated again and of course this will minimize discrimination. [1]

Awareness of the principle of equality before the law has long been proclaimed. The Indonesian government has poured that word into the Basic Law, showing that the founders of the Indonesian state were well aware of the importance of protecting human rights even before the Indonesian state was officially established. In addition, Indonesian legal documents and 
regulations legally recognize the principle of equality between men and women at the international and national levels.At the level of national governance, discrimination and injustice against women in employment, including in the fields of economy, education, health and politics, are always left behind and left behind. It is also influenced by the existence of a widespread culture and patriarchy that lives in the indigenous people of Indonesia. In patriarchal culture, men are more positioned as rulers and can automatically reduce women's roles and titles. In other words, discrimination in society has indirectly taken root and developed along with the growth of indigenous people themselves.

An independent and advanced nation is a nation that has a strong, intelligent and resilient generation. The future of a nation will be reflected in the formation of the character of the next generation of the nation itself. To create an intelligent, strong and resilient generation, starting with an education rooted in the culture of a nation. Education should be given as early as possible and able to touch every Indonesian child to create a generation of character and educate the life of the nation. Of course in terms of education, children should not be separated, even as the nation's successors, as human scholars, are an integral part of human survival. As a next generation state, children must stand under one roof and guarantee all rights. Under Indonesia's Constitution, the state guarantees all children the right to survival, growth and development, as well as protection from violence and discrimination. This shows that the interests of children are prioritized and positioned as the best interests for the survival of a country that is increasingly qualified every year. Children are part of the younger generation as one of the talented people to play a strategic role and achieve the ideals of the struggle of a nation of special character. Therefore, children urgently need special protection to ensure physical, mental and social growth and development. Protection must also be careful, intact and of course sustainable.

The state is responsible for ensuring the constitutional welfare of the child in the 1945 Constitution. Different legitimate products are hierarchically enforced and ratified. This becomes the basis of Indonesia's childcare policies and guidelines. In this regard, one of the legal artifacts that has been ratified by Indonesia is the Treaty on the Rights of the Child and its Protocol through Presidential Decree 36/1990 and Law 5/1998 which ratified the Convention Against Torture. Or punishment, including for the unfair treatment of humanity that degrades human dignity. From an international perspective, the role of the international community in monitoring the performance of children's rights under the Convention on the Rights of the Child has a positive impact on the development of child protection in Indonesia. Child protection is also regulated in Law No. 35 of 2014 on Child Protection, which affirms that child protection organizers are parents, families, governments, and countries. Although various child protection regulations have been established, both blind regulations and other factors have increased child protection violations over time.

Violations of child protection in this case are often referred to as the phenomenon of violence against women and children that is still a hot conversation in the community. But in every area there are always cases of violence against children and women. The most common form of violence against women, domestic violence (KDRT), is rarely a victim of this violence, including children. Examples of domestic violence show that the phenomenon of violence against women and children occurs on the smallest scale, namely in the family (home). It also shows that violence is part of the family life of many families in various regions of Indonesia.

Departing from these problems, of course, an improvement in legal material products, the development of apparatus, legal facilities and infrastructure is needed. Because as we know the regulations and related regulations have not been followed by concrete steps and 
seriousness of the government and law enforcement officials in implementing and enforcing the law. So that the applicable regulations have not been able to bind all levels of society to be aware of the law on this serious issue. Defects in regulation such as disruption in the judicial process and legal overlap that resulted in a legal crisis in Indonesia and led to cases of crime, one of which was violence against women and children. This harsh legal condition has resulted in the protection and respect for human rights in Indonesia is increasingly alarming. It is also assessed from various human rights violations that occur in Indonesia, including in the form of acts of violence, discrimination, and violence.

This serious issue is not only in the national public spotlight, but also seen by the international public. Until now Indonesia is still highlighted by the international community considering that Indonesia is also known as a source of human trafficking activities. Based on the Annual People Trafficking Report of the U.S. State Department, in the period April 2001March 2002. Indonesia belongs to the Category of Tier-32 countries, namely; Countries that simply do not meet the minimum standards in combating trafficking in persons.

There are concerns about the emergence of various forms of human manipulation and exploitation, especially against women and children as a result of the rampant crime of human trafficking, not without reason. Many examples can be given to women and children, who should receive appropriate care instead, exploited for a specific purpose. In fact, women and children are creations of Almighty God and need to be protected for their dignity and dignity, and their right to life is guaranteed to grow and develop according to their nature and nature. Therefore, any form of treatment that interferes with and destroys their basic rights in various forms of inhumane use and exploitation must be stopped immediately without exception.

\section{Discussion}

\section{The Position of the Children and Woman in Human Rights}

Human rights are fundamental fundamental rights and should be held in high esteem by every level of society without exception. Human rights give moral power to guarantee and protect human dignity based on law, not against the will of individuals let alone politics. Human rights are owned by every individual regardless of ethnicity, race, culture or religion. So that every human being is aware and submissive to it. However, it is unfortunate that not all human beings are able to appreciate differences and diversity based on human rights. Therefore, the government must then intervene decisively to remind the whole community of human rights and uphold equality for all citizens without exception and regardless of the gender of men or women. The existence of human rights in Indonesia is absolutely applicable and must be protected for all citizens, but in addition to human rights there are also human rights. Because we do not allow the implementation and enforcement of human rights, there is a link between human rights and human rights with mutually influencing obligations, and if obligations are not met, human rights enforcement will not be achieved reliably. Therefore, human rights must be affirmed to all individuals in society, not least in children and women.

Various laws and regulations in Indonesia have different restrictions on children, but in principle the diversity of these restrictions has the same effect on child protection. According to Article 23, Article 1 (1) of the 2002 Law, "A child is any person who is not yet 18 years old (18 years old), including a child who is still in the womb". Meanwhile, CRC Article 1/Executive Order No. 36 of 1990 "Children under the age of 18, except under the law governing early arrival in adulthood." [2] Furthermore, according to Article 1(5) of Human Rights Law No. 39 of 1999, "A child is an unmarried person under the age of 18, including a child who is still in the womb, if any. his interest". Various violations of children's rights that 
still occur frequently, reflected in the still existence of children who experience abuse, violence, exploitation and discrimination.

In the Explanation of Article 5 paragraph (3) of Law No.39 of 1999 mentioned that those who belong to vulnerable groups are the elderly, children, poor, pregnant women, and people with disabilities. Therefore explicitly only pregnant women belong to the Vulnerable Group. The Great Dictionary Indonesian formulates the definition of vulnerable as: (1) susceptible to disease and (2) sensitive, easy to feel.

This weak group is usually unable to help themselves, so they need the help of others. In addition, vulnerable groups are also interpreted as impressionable groups. The second understanding is a logical consequence of the first understanding, because as a weak group it is easily influenced. Empirically Domestic Violence (KDRT) has long been ongoing in society, only in quantity is not yet known the number, such as husband and husband violence against female domestic helpers. Forms of violence also vary from persecution, rape and so on. In addition, the fulfillment of the rights of vulnerable women is not only limited to protection in the household, but also related to women's reproduction. Sociologically most women are still severely constrained by the culture of society, where traditional roles are still attached strongly, which indicates that women are nothing more than wives or housewives alone.

In the family and most societies, women do not have their own identity because it belongs to her husband's legal personality. Therefore, marriage is not an equal partnership. The use of family units by political, economic and social professionals is one of the causes of implicit barriers for women to participate in politics. The family is often seen as a place of institutionalization of the "female inferiority complex" and the "male superiority complex" because men are traditionally considered suitable as heads of families. Traditional family structures create different divisions of rights, obligations, time, and values for each family.

The issue of human rights is increasingly raised because of the notion that genderinsensitive human rights are not actually enjoyed by many women and women's human rights have not been protected. Crimes against humanity are still a part of social life. In many cases the most abused victims are women and children who are often raped and subjected to various forms of sexual violence.

\section{Efforts of the Government of Indonesia to uphold the human rights}

Efforts are underway to protect the human rights from across the country. In Article 4 of the Amendment to the Constitution of the Republic of Indonesia in 1945, Chapter XA regulates human rights.[3], The inclusion of the 1945 Constitution in the formulation and respect, protection, implementation and guarantee of human rights progress is a desire to consider the development of views on human rights that are increasingly seen as a global issue, not just about it. But that's why it's one of the state's conditions of law. [4], [5]. The implementation of human rights in the 1945 Constitution guarantees the human rights of all Indonesian people and citizens. In this case, the Indonesian people need to pay attention to the details of Indonesia, and it is expected that human rights will be weighed with obligations, mutual respect and respect for the human rights of each party. [6]. One aspect of human rights education in the 1945 Constitution is related to human rights welfare. The same rights and obligations of all citizens in all spheres of life are prerequisites for achieving the social welfare of all Indonesians. One aspect of the 1945 Constitution that stipulates human rights is related to human rights welfare. The same rights and obligations of all citizens at all levels of society are prerequisites for achieving the social welfare of all Indonesians. [7].

With the issuance of the Opening of the Constitution of the Republic of Indonesia on the 18th Universal Declaration of Human Rights of 1945, the Indonesian nation has officially 
declared human rights for the first time in history. Declared August 18, 1945. 1948 United Nations Human Rights. This is a fact that shows the world that the Indonesian nation upholds human rights in its own country before the UN Declaration of Human Rights. Human rights are the basic rights and gifts of God Almighty which are essentially related to the nature and existence of man as a being. Human rights must be respected, protected, fulfilled, supported and promoted for the dignity and values of humanity. The enforcement of respect, implementation, protection, enforcement and promotion of human rights is essentially the mission and responsibility of the state, especially the government. It is regulated in Article 28I (4) of the Constitution of the Republic of Indonesia of 1945 and Article 71 of Law No. 39 on Human Rights of 1999.

Since the law essentially reflects human rights, the inclusion of justice in the law is determined by the human rights contained therein and regulated or guaranteed by the law itself. The law is no longer understood as an image of mere power, but must also reflect the protection of citizens' rights. Laws based on human values reflect norms that respect human dignity and recognize human rights themselves. Norms, including noble values that protect dignity and human dignity and guarantee human rights, are tools that enable citizens to develop their talents in order to carry out their duties properly. This possibility is carried out by the state by forming legal rules or regulations which are an important task of the state. Freedom is guaranteed by the state by forming legal rules or regulations, which is an important task of the state. Freedom is guaranteed by the state by forming legal rules or regulations, which is an important task of the state. Freedom is guaranteed by the state in the interest of society. Legal rules that enable community members to develop their talents are beneficial for the development of law and the achievement of legal order.

Positioning children as the younger generation, preserving the noble ideals of the nation, becoming the future leaders of the nation and nation, and a source of hope for previous generations. It must be protected to maximize the potential for proper mental, physical and social growth and development. Child protection is the effort and activity of all social classes in different positions and roles and fully realizes the importance of the child to the future of home and country.[8]. As they mature in physical or mental and social development, it's time to replace previous generations.. [9] Child protection emphasizes efforts to protect children in order to carry out their rights and obligations. Allowing children to express themselves freely both in the social sphere and themselves.

Child protection is also concerned with his physical and mental needs, so that the growth and development of a child does not experience any disability or disability in his growth and development[10]. Article 2 of Law No. 23 of 2002 on the Protection of the Child states that the principles or principles of the Convention on the Rights of the Child include, among others: (1) Indiscriminate. In this case, indiscriminate means everything. The rights recognized and included in the Convention on the Rights of the Child are: These should be applied indiscriminately to all children. (2) The best interests of the child d. NS. The best interests of the child should be the highest priority in all actions involving the child undertaken by the government, society, legislature and judiciary.[11]-[16].

Article 23 of the 2002 Law on Child Protection contains the following provisions: A. All children are entitled to protection from financial and sexual neglect, cruelty, violence and abuse, discrimination and exploitation of both injustice and other arbitrariness. B. If a parent, guardian, or legal guardian performs all the treatments set out in paragraph 1, the offender will be punished with a higher fine. Children should be protected from being direct or indirect victims of the actions of others (individuals or groups, private or state organizations). Sacrifice here means suffering psychic, physical and social losses. In essence, the child 
cannot protect himself from various types of crimes that harm each other in life and in various areas of life. [17].

Trafficking in persons is international, domestic or international, for the purposes of violence, use of force, kidnapping, imprisonment, fraud, fraud, abuse of power or abuse of threatened positions, slave debt, or the exploitation or exploitation of persons with the consent of those who control others. The protection of women and children from any activities aimed at illegal exploitation is actually a form of protection of human rights, innate rights acquired from birth, and the irreparable gift of God [18].

Any form of trafficking of women and children is a violation of human rights, children's rights and the rights of workers who victims treat as commodities to be bought, sold, shipped or resold. This global phenomenon is constantly evolving, changing its shape and complexity, which is nothing more than an exploitative condition towards humans. Because exploitation of women and children tends to increase quantitatively and qualitatively year after year, engagement is a very important factor in all walks of life in addressing the rise of human trafficking. Frank Tannenbaum cites the phenomenon of crime increasing quantitatively and qualitatively [19], states, crime is eternal-as eternal as society, meaning that where there are humans there must be evil.

Norms, including lofty values that support dignity and human dignity and guarantee human rights, continue to evolve in accordance with the demands of human conscience. Therefore, it is also reflected in some of the guidelines of laws and regulations that protect women and children. When the law is essentially a reflection of justice, and the law is no longer merely a reflection of power, it must also reflect the protection of all citizens.

In the context of the protection of human rights, the protection of women and children is one form of the right to life, slavery or freedom from slavery. [20]. It's eternal and universal. This means that it applies to everyone regardless of origin, gender, religion, or age, so every country must take care of it without exception. Maintaining the quality of human resources requires ongoing efforts to protect women and children, such as preventing eradicating human and trafficking. We protect adults and men because everyone is equal before the law.

\section{Conclusion}

The legal protection of women and children from a human rights perspective is essentially the parent to fulfil and guarantee the rights of all children as provided for in the 2014 Convention on the Rights of the Child and Law No. 35. Efforts of government and society. child. Protection is guaranteed. There is no legal protection for children in terms of human rights, because the government has not fulfilled its obligation to fulfill the rights of children and there are still violations of rights against children. Preventive law protection reduces and prevents violence against children and women under rules that protect the interests of children and women.

Prosecutions not only enforce laws and regulations, but also enforce court decisions. In other words, law enforcement is also an effort to provide legal protection to the community. Society needs to abide by positive laws in order to be understood and followed. This ensures that everyone is treated equally legally and their rights are legally protected. We can guarantee. Basically the law must realize the right to be manifested in equality before the law, the principle of protection of children and women, especially normative rules that depend on achieving good legal protection for children and women. Society also positions the child as the harmony of life (everything). This is important because the handling of human trafficking 
is done seriously and not half-and-half. Government should be more focus at their responsibilities.

\section{References}

[1] D.G. S. Brata, D.P., Yuliartini, N.P. R., \& Mangku, "Juridical Review of The Principle of Open Hearing To The Public In Broadcasting Criminal Proceedings," J. Yust.Community, vol. 3, No. 1, pp. 330-339, 2020.

[2] N.P.R. Astuti, N.K.N., Mangku, D. G. S., \& Yuliartini, "Implementation of Pistole Rights Against Prisoners of Confinement in Correctional Institution Class II B Singaraja.," J. Yust.Community, vol. 3, No. 1, pp. 37-47, 2020.

[3] D.G. S. Parwati, N.P. E., Yuliartini, N.P. R., \& Mangku, "Juridical Study of On-Site Shooting Authority By Densus 88 Against Terrorism Suspects Linked to HA," J. Yust.Community, vol. 2, no. 2, pp. 191-200, 2020.

[4] P. R. A. Malik, F., Abduladjid, S., Mangku, D. G. S., Yuliartini, N. P. R., Wirawan, I. G.M. A. S., \& Mahendra, "Legal Protection for People with Disabilities in the Perspective of Human Rights in Indonesia," Int. J. Criminol. Sociol., vol. 10, pp. 538$547,2021$.

[5] D. G. S. Mangku, "A General Study on International Dispute Resolution Included in the ASEAN Body," Perspective, vol. 17, no. 3, 2012.

[6] N. P. R. Sakti, L. S., Mangku, D. G. S., \& Yuliartini, "State Responsibility for Marine Environmental Pollution Due to Oil Spills At Sea Borders Indonesia With Singapore According to International Sea Law," J. Komunitas Yust., vol. 2, no. 3, pp. 131-140, 2020.

[7] T. Obokata, Trafficking of Human Beings from a Human Rights perspective: Towards a more holistic approach (Vol. 89). Martinus Nijhoff Publishers, 2006.

[8] D. G. S. Mangku, "Implementation Of Technical Sub Committee Border Demarcation And Regulation (TSC-BDR) Agreement Between Indonesia-Timor Leste In The Resolution Of The Land Border Dispute," J. IUS Kaji. Huk. and Justice, vol. 8, no. 3, pp. 405-419, 2020.

[9] A. Gosita, Child Protection Issues. Jakarta: Pressindo, 2004.

[10] N. P. R. Lindasari, L. E., Mangku, D. G. S., \& Yuliartini, "Legal Protection of Diplomatic Representative Buildings Reviewed From the Perspective of the 1961 Vienna Convention (Case Study: Suicide Bombings In Kabul Afghanistan Near the United States Embassy)," J. Educator. Citizenship of Undiksha, vol. 8, no. 3, pp. 2941, 2020.

[11] D. G. S. Yuliartini, N. P. R., \& Mangku, "Acts of Genocide against the Rohingya in the Perspective of International Criminal Law," Maj. Ilm. Cakrawala Huk., vol. 21, no. 1, pp. 41-49, 2019.

[12] N. P. R. Yuliartini, "Child Delinquency in The Phenomenon of Wild Racing in Singaraja City in Criminology Study," J. Advocacy, vol. 9, no. 1, pp. 31-43, 2019.

[13] N. P. R. Yuliartini, "Legal Protection For Victims Of Criminal Violations (Case Study Of Violence Against Children In Buleleng District)," Veteran Law Rev., vol. 2, no. 2, pp. 30-41, 2019.

[14] N. P. R. Yuliartini, "Legal Protection of Women And Children From Violence In The Perspective Of Regional Regulation of Buleleng Regency Number 5 Year 2019," J. Educator. Citizenship of Undiksha, vol. 9, no. 1, pp. 89-96, 2021.

[15] D. G. S. Yuliartini, N. P. R., \& Mangku, "Investigation of Children as Perpetrators of 
Crimes of Persecution That Resulted in Death (Case Study In the Jurisdiction of the Buleleng Resort Police)," J. Educator. Citizenship of Undiksha, vol. 8, no. 3, pp. 145154, 2020.

[16] D. G. S. Yuliartini, N. P. R., \& Mangku, "The Role of the Buleleng Regency Transmigration Labor Office in the Placement and Provision of Protection of Indonesian Labor Law Abroad," J. Educator. Citizenship of Undiksha, vol. 8, no. 2, pp. 22-40, 2020.

[17] R. J. (Ed. ). Cook, Human rights of women: National and international perspectives. University of Pennsylvania Press., 2012.

[18] A. Hamzah, Protection of Human Rights in the Criminal Procedure Law. Bandung: Binacipta, 1986.

[19] J.E.Sahetapy, "Crime Tsa," Center for Criminology Studies, Faculty of Law, Universitas Airlangga, 1979.

[20] G. Binion, "Human rights: A feminist perspective," Hum. Rts. Q, vol. 17, p. 509, 1995. 